\section{Extractive industries in fragile states and the role of market incentives and regulation}

\section{Gilles Carbonnier}

A crucial question facing parts of sub-Saharan Africa is how oil and mining booms can be turned into a development opportunity rather than a source of violence and misery. Primary commodities, and extractive resources in particular, have long been recognized as a significant vehicle for shaping development prospects in fragile states, but in many cases they have led to the so-called resource curse, where countries discovering abundant natural resources have seen lower economic growth and human development than resource scarce ones. In addition, natural resource abundance has been associated with poverty and armed conflict in fragile institutional settings.

Although several authors question the empirical validity of the resource curse argument, there is a growing consensus that resource abundance can be detrimental to developing countries whose state institutions are weak. The underlying mechanisms that contribute to the phenomenon remain yet unspecified and most academics and policymakers agree that natural resources can and should be an opportunity for development, pointing to countries such as Botswana or Malaysia as success stories. But while they also emphasize that sound resource management is possible, the clarity and evidence is scant on the processes and instruments necessary to turn the curse into a blessing.

Global policy initiatives on increasing revenue transparency in fragile and resource abundant states exist, of which the Extractive Industries Transparency Initiative (EITI) is probably the central international response. At the time of writing (June 2009), the EITI is at a critical phase as 29 candidate countries have to acquire “compliant status” over the next eighteen months, which means translating substantial transparency commitments into legislation and practice in a variety of countries, ranging from the Republic of Congo to Norway. This is a daunting challenge, but if the EITI proves to be a success, it will inspire similar undertakings to address global development challenges elsewhere. If it fails, it will seriously put into question the value added and potential of such multi-stakeholder governance mechanisms.

The article first reviews the evidence on the relationship between extractive resources, state fragility, and the resource curse before considering current policy initiatives that aim to address the curse and then evaluates the potential for the use of market incentives and regulation. Conclusions and avenues for further research are presented, some of which are being pursued as part of a larger research project on the global and local governance of oil and mining in sub-Saharan Africa and Latin America.
Extractive resources and fragile states

Oil and minerals are among the top geostrategic priorities of virtually all states and societies and likely to become more important. It is estimated that world demand for oil and gas will increase by 45 percent between 2006 and 2030 because of demographic pressures and economic growth in the developing and emerging economies. African oil represents the last frontier of oil exploration and as new African oil-producing countries have not yet established strong state-owned companies, this provides great opportunities for foreign companies. American, French, and Chinese competition over oil exploration and exploitation rights in Chad, some of which had already started in the 1970s, illustrate the "scramble for Africa's oil" that has been taking place. It also has growing strategic importance for Western countries. By 2006, 23 percent of U.S. oil imports came from Africa compared with only 18 percent from the Persian Gulf. Africa exported USD249 billion in oil and minerals that year, six times more than the amount of foreign aid it received. ${ }^{1}$

Within producer countries, oil and gas sectors have become increasingly important, with taxes on oil and gas production accounting for more than 50 percent of total government revenues for most resource rich sub-Saharan African countries. Over half of their gross domestic product comes from fuels and mineral exports: oil and gas contributed 87 percent to Equatorial Guinea's GDP, 70 percent to Congo's and 57 percent to Angola's GDP, much higher than official development assistance. At the same time, two-thirds of the world's fragile states are concentrated in sub-Saharan Africa, including in resource-rich Angola, DRC, Congo-Brazzaville, Nigeria, and Sudan. State fragility exacerbates the risk of armed conflict in resource-rich countries as access to resources may provide insurgents the means to challenge the state, and oil and mining booms often benefit the politico-economic elite while the majority of the population is left in dire poverty. Such conditions represent an ideal breeding ground for social unrest and armed violence. Fragile states are also seen as a threat to regional and global security because of proliferating armed conflict, terrorism, migration, organized crime, disease, and environmental degradation. ${ }^{2}$

In the literature, debate has focused on both macroeconomic issues, such as Dutch disease and rentier-state theories, and microeconomic issues, such as the incentives provided by resource abundance for violent behavior. It has shown that natural resources are more important to the perpetuation rather than the onset of conflict, as rent capture does not only serve to finance war but can become the main reason for continuing the fighting. It has been argued that, while the abundance of natural 
resources broadly defined as primary commodities is not correlated to the onset of civil war, the abundance of extractive resources is. Hence, research looked closely at conflict-prone countries richly endowed in oil and gas, metals, timber, and gemstones that can easily be extracted and marketed by rebels. The results of this research have informed several policy responses over the past decade, including fiscal transparency (e.g., EITI), revenue-sharing deals in peace agreements (e.g., North-South Sudan), the introduction of conflict sensitivity in business practices, through instruments such as peace and conflict impact assessments, the curbing of conflict finance (e.g., targeted sanctions by the UN Security Council and expert panel reviews, and the transforming of war economies by spurring investment, diversifying the economy, and creating decent jobs in the formal sector. ${ }^{3}$

It became apparent that to avert the rekindling of tension and a resumption of armed conflict, the linkages between resource extraction and violent conflict needed to be reflected in peace agreements and peacebuilding strategies to favor equitable revenue-distribution patterns. One of the key aspects of a durable peace after violent conflict is building a state with the ability to collect public resources and to manage expenditure in a manner that is acceptable for key constituents, while resource rents need to be kept out of the reach of peace spoilers. ${ }^{4}$

In addition, the importance of the links among oil extraction, global warming, and development became apparent, leading to calls for better resource management schemes. Oil consumption in energy generation or combustion engines is a major source of carbon dioxide and some of these emissions could rather usefully be averted. For example, in African oil producing states, a total of 40 billion cubic meters of gas was flared in 2005, corresponding to more than three times the entire African gas consumption. At the same time, two-thirds of households in the region do not have access to electricity and three-quarters do not have access to clean cooking fuels. ${ }^{5}$

\section{The resource curse}

Until the 1980s, economic orthodoxy generally considered resource abundance as a powerful engine of development spurring capital investment and boosting exports. Prebisch and Singer, however, hinted at the natural resource trap associated with the constant deterioration of the terms of trade. The idea that natural resources might be more of a curse than a blessing became conventional wisdom by the end of the cold war, as research demonstrated that extraction of commodities such as oil, gas, and minerals was often associated in weak states with extreme poverty, repressive regimes, environmental degradation, and civil war. Following Auty's use of the term "resource curse" to describe how countries with abundant natural resources had lower economic growth than countries poorly endowed in natural resources, researchers refer to three main economic, institutional and political dynamics. ${ }^{6}$

First, economists documented that high oil or mining export earnings tend to push real wages and the domestic currency value upward, which damages other export sectors and economic diversification efforts, resulting in the so-called Dutch disease. The volatility of commodity prices and the presence of boom-and-bust cycles have also been cited for low growth in resource-rich countries. Second, researchers argued that political and institutional dimensions of the phenomenon are important. Political scientists point to the rentier-state theory and the role of neo-patrimonial networks, arguing that oil rent is detrimental to democracy reducing accountability and increasing corruption. Delivering economic growth and employment opportunities to a large part of the population is less rewarding. Third, research on the causes of civil war underlined the role of rent-seeking behavior of the ruling elite and the insurgency, making civil war and their perpetuation more likely. The often cited finding that "primary commodity exports substantially increase the risk of armed conflict" has not been validated by cross-sectional empirical studies, nor case studies, and is not a robust result. Instead, the origins of armed conflict reflect multiple interacting disputes and security dilemmas and cannot be minimized to mono-causal explanations. ${ }^{\text {? }}$

\section{Countering the resource curse}

Academics and policymakers alike agree that it should be possible to deal with the resource curse and make resource discoveries an opportunity for development. Economists have emphasized the crucial role of prudent fiscal and budgetary policies, economic diversification, natural resource funds, and direct distribution for managing resource wealth to ensure investment in public goods, citing the successes of Botswana, Chile, and Malaysia. However, these policy prescriptions rest on the assumption that strong and efficient state institutions exist, and, to a lesser degree, on the presence of legitimate state ownership of resources, two elements that are largely absent in fragile states. ${ }^{8}$

Because of the nature of the rentier state, taxation and trade play an important role in fostering sound state-society relations based on mutual accountability. International and domestic efforts have focused on increasing the transparency of national resource revenues and dealings with international corporations, effectively limiting market access by "rough" companies, tracking the financing of illicit commodities, and demanding responsible behavior from companies in their dealings with the governments of resource rich countries. To deal with weak state institutions some have advocated domestic private ownership of resources to improve resource management. Others have argued that at a sub-state level classic state functions are delivered by nonstate actors, and that these can be strengthened through changing the management of the state's revenue from oil and mining. Recent suggestions on governance include "mediated states," “pockets of effectiveness,” as well as "limited access orders.” However, these processes remain little understood. ${ }^{9}$

The international aid community has recognized the problem of weak political institutions and the World Bank has made support for extractive industry investment 
one of the cornerstones of its approach to poverty reduction in sub-Saharan Africa and has based its financial provisions on explicit poverty-reduction conditionality for oil-rich African states. The International Monetary Fund also promotes greater transparency and the establishment of special funds to manage petroleum revenues. The best-known attempt by the World Bank, however, is related to the Chad-Cameroon pipeline, backed financially by the International Financial Corporation, and this showed the very limited leverage international organizations have in resource-rich fragile states. ${ }^{10}$

\section{Multi stakeholder initiatives}

In response to campaigns by nongovernmental organizations, since 2003 governments and international organizations have been partnering with oil and mining companies, civil society, and investors in the EITI. This requires companies to publish what they pay and governments to disclose what they receive. The expectation is that developing countries will benefit from implementing a standardized and internationally recognized procedure for transparency in natural resource management, one that improves the investment climate and increases governance performance. Certainly, the international development community views revenue transparency as one of the most crucial elements to curb corruption and address institutional weaknesses in resource-rich countries. This high level of priority given to transparency is nonetheless questioned by scholars who argue that the impact of transparency depends on the capacity of those who access information to process it and the incentives and ability to act on this information. This is turn depends on the education level of the electorate and its capacity to hold the government accountable. ${ }^{11}$

New forms of governance have emerged through which a range of stakeholders from the public, private, and civil society sectors gather to create regulatory frameworks in order to tackle a given challenge. In the extractive sector these aim to reinforce security and human rights, such as the Kimberley Process, a certification scheme for the trade in conflict-free diamonds, or the Voluntary Principles on Security and Human Rights for the extractive sector. The Kimberley Process was launched in 2003 to prevent diamonds from fueling armed conflict and civil war. Yet its implementation proved to be extremely challenging. The EITI that came into being in 2003 as well faces no smaller challenges. The civil society coalition Publish What You Pay criticizes that the EITI validation process is moving slowly, with only one country so far having gone from candidate to compliant status (Azerbaijan). Moreover, they worry that candidate country's governments may be using EITI to gain Heavily Indebted Poor Country status without being committed to actual implementation. ${ }^{12}$

The EITI would seem to represent a promising, yet fragile, new form of governance and the next two years should allow its success to be gauged on several fronts: First, measuring the impact in the field, that is, the degree to which the
Initiative has achieved its stated goal of providing a sufficient level of transparency on extractive firms' payments to governments and how far the transparency requirement has been translated into national legislation. Second, measuring the impact of the multi stakeholder initiatives on the stakeholders themselves, exploring how far the business and social drivers for joining the EITI have materialized for each stakeholder. Third, the wider impact of the EITI will be measured by the emergence of effective checks and balance mechanisms in producer states. Much of its success may depend on a proper understanding of the workings of incentives and regulations, and how business and civil society can contribute to shaping them in multi stakeholder initiatives in order to address the resource curse. Such multi stakeholder initiatives generally revolve around either operational cooperation, where their legitimacy is derived from their impact and achievements on the ground, and normsetting and policymaking, where legitimacy relies more on the procedural and deliberative mechanisms, decisionmaking processes, and democratic legitimacy (input legitimacy). ${ }^{13}$

\section{Market incentives and regulation}

The behavior of companies is conditioned by incentive structures and regulatory frameworks. Thus, any global response to the resource curse calls for new avenues for action, particularly from nonstate actors, in their capacity to influence the regulatory framework and market incentives. ${ }^{14}$ This role for investors, extractive industries, local civil society organizations, and international NGOs has, however, received limited attention in the literature to date.

Investment decisions by extractive firms tend to be dictated by geology, which increasingly force them to invest in fragile states and sensitive environments. Confronted with high levels of instability, they need to build relatively long-term relationships with governments and so generally they do not like to engage the authorities on sensitive political issues_-such as human rights or revenue transparency — as this could be to their commercial disadvantage. ${ }^{15}$ Market forces and regulations can, however, be used by multi stakeholder initiatives, to provide both positive and negative incentives and so to influence the behavior of the oil-producing states and extractive companies. Such incentives are typically transmitted through financial and consumer-good markets. In this context, investors and financial intermediaries are called upon to play an increasingly active role.

Global financial institutions provide the significant amounts of capital required for exploration and exploitation, as well as providing insurance or export-credit guarantees to limit exposure to commercial and political risks. Thus they can provide important incentives to influence the behavior of oil-producing governments and extractive industries. In the EITI, over 70 institutional investors and asset managers have joined the process and look to influence behavior via their investment decisions and by active engagement with company executives. Stock market supervisory 
authorities can adopt regulations to foster transparency from listed companies in the extractive sector. In 2008, the Congress of the United States of America has dealt several times with the issue of oil and mining transparency and how to counter the oil curse. Parliamentarians are considering the adoption of the Extractive Industry Transparency Disclosure Act (EITDA), which would require full disclosure of payments to host countries by the largest oil and mining firms that are listed on U.S. capital markets, including Chinese, Indian, and Brazilian companies. ${ }^{16}$ At the level of oil and mining commodity markets, research is simply lacking at present. Oil prices are indexed on futures contracts and thus primarily function as financial markets and so price determination is remote from the real economy and the physical products. One possible action that has been suggested is to set the price of oil and gas through an auction system to reduce damaging price volatility. ${ }^{17}$

International financial institutions, such as the IMF, the International Finance Corporation (part of the World Bank Group), and regional development banks, have considerable leverage in promoting transparency and sound governance practices in the extractive sector, notably through policy dialogue and conditionality attached to development finance and project finance. Bilateral donors can also send important signals via their export-credit agencies and aid programs. Indeed, development finance has been used for decades as an instrument to induce recipient governments to adopt certain policies, although experience has shown the limited effectiveness of aid conditionality when there is no political buy-in. Donors can exert significant influence as long as foreign aid represents a significant portion of the recipient budget and as long as revenues from extractive resources are not large enough to shield resource-rich countries from such pressure. ${ }^{18}$ Table 1 provides selected examples of options for shaping incentives and regulation with a view to addressing the resource curse.

In the case of oil and gas, consumers cannot exert any pressure as long as the product they buy is not traceable, that is, the origin of oil remains unknown, although oil experts have hinted that traceability could be substantially improved if there is sufficient political will. ${ }^{19}$

An emerging literature emphasizes the link between natural resource governance and political incentives. One pair of authors, for example, argues that if natural resource funds (NRFs) “do not substantially affect political incentives they can be ignored or bypassed by governments and have no beneficial effects.” In most settings natural resource wealth leads to a temptation to overspend in unproductive activities in the present, leaving less for future generations. This is often linked to competition for political power and the creation of patronage networks. Empirical work on NRF management indicates three institutional solutions. First, to set clear and binding rules that govern the magnitude and composition of disbursement and so to shift natural resource policymaking from discretionary toward rule-based practices. Second, to separate decisionmaking authority between "how much is spent" and "what it is spent on," allowing different constituencies both within and outside the government to
Table 1: Selected options for incentives and regulations

\begin{tabular}{|c|c|c|}
\hline & Incentives & Regulatory measures \\
\hline Capital market & $\begin{array}{l}\text { Shareholder activism, ethical } \\
\text { guidelines and investment } \\
\text { decisions by institutional investors } \\
\text { (e.g., Santiago Principles for } \\
\text { Sovereign Wealth Funds), GRI } \\
\text { indicators }\end{array}$ & $\begin{array}{l}\text { E.g., draft U.S. EITDA Act; } \\
\text { revision of international accounting } \\
\text { standards (IFRS } 6 \text { and } 8 \text { ) set by the } \\
\text { International Financial Accounting } \\
\text { Board }\end{array}$ \\
\hline Project finance & $\begin{array}{l}\text { Equator Principles and IFC } \\
\text { environmental and social standards }\end{array}$ & $\begin{array}{l}\text { Export credit agencies' } \\
\text { requirements for investing in } \\
\text { extractive projects }\end{array}$ \\
\hline $\begin{array}{l}\text { Commodity } \\
\text { markets }\end{array}$ & \multicolumn{2}{|c|}{$\begin{array}{l}\text { Incentives and regulations in commodity markets largely remain } \\
\text { unexplored, e.g., discussion on auction system for oil }\end{array}$} \\
\hline $\begin{array}{l}\text { Development } \\
\text { finance }\end{array}$ & $\begin{array}{l}\text { Environmental, social, and } \\
\text { transparency standards set by aid } \\
\text { agencies }\end{array}$ & $\begin{array}{l}\text { Ex-ante and ex-post conditionality } \\
\text { clauses in aid programs }\end{array}$ \\
\hline Trading & $\begin{array}{l}\text { Improving traceability throughout } \\
\text { the entire supply chain; } \\
\text { differentiating products, including } \\
\text { through taxation }\end{array}$ & $\begin{array}{l}\text { Import and trade regulation (debate } \\
\text { on "like products" and PPMs under } \\
\text { the WTO) }\end{array}$ \\
\hline $\begin{array}{l}\text { Consumer } \\
\text { markets }\end{array}$ & $\begin{array}{l}\text { Consumer activism, fair trade, } \\
\text { product differentiation, taxation } \\
\text { and subsidies }\end{array}$ & $\begin{array}{l}\text { Import regulation, labelling } \\
\text { requirements }\end{array}$ \\
\hline
\end{tabular}

screen, comment, and perhaps even change policy. Third, to define rules for transparent reporting practices which allow more effective monitoring and disciplining of the government by civil society or political parties. ${ }^{20}$

The adequacy of natural resource funds and "future generation funds" is questionable. Why invest in Wall Street rather than in domestic African economies? Investment opportunities and return rates are considerable, starting with the infrastructure and energy sectors. ${ }^{21}$

\section{Conclusion and further research}

In the absence of a global governance mechanism for energy and extractive resources, policymakers have started to address specific dimensions of the so-called resource curse over the past decade, contributing to several multistakeholder initiatives such as the EITI. These initiatives often entrust civil society organizations (CSOs) with the task to put pressure on governments and industries for implementation and to act as 
a watchdog. CSOs are expected to constrain the power of the politico-economic elite in producer states, for instance by demanding more transparency and accountability over extractive revenue. The outcome to date remains below expectations. It tends to confirm that civil society alone cannot radically alter elite's rent-seeking behavior, in particular in autocratic states where civil society organizations have traditionally been weak, divided, or nonexistent. Against this background, market incentives and regulation are critical in putting additional pressure on the elite, as recently illustrated by the Kimberley Process Certification Scheme for diamonds. The deal was struck after just three years of negotiations: the diamond industry and producer states felt it necessary to swiftly address the risk of a consumer boycott in response to the campaign against blood diamonds. The situation is different in the oil and gas market. Consumers cannot vote with their purse when purchasing fuels because products from diverse origins are blended before reaching the consumer market. In such cases, the financial market and development finance have the potential to send strong signals to producer states and extractive firms in favor of enhanced transparency and accountability. Regulation must also play a role beyond incentives. The EITI would for instance receive a welcome and necessary boost if stockmarket authorities require full transparency on payments made to host and home governments by publicly-listed oil and mining companies.

This investigation into market incentives and regulation is embedded into a larger research project on the global and local governance of oil and mining conducted by the Center on Conflict, Development and Peacebuilding, Geneva, in partnership with research institutes in Africa and Latin America. Future work will examine the following propositions:

- That nonstate actors, civil society, and investors in particular can contribute to countering the resource curse if market and political incentives are right;

- That targeted market incentives and regulations help counter the resource curse by changing the behavior of governments and economic actors (investors, trading firms, extractive industries, project and development finance), in producing and importing countries;

- That market incentives and regulations can counter the resource curse by radically altering the risks and benefits associated with and accountability (or lack thereof) for companies and governments;

- That multi-stakeholder initiatives such as the EITI represent an important, but by no means sufficient standard and governance mechanism to address the resource curse.

As illustrated, a variety of optional incentives and regulatory measures can contribute to addressing the resource curse and further research will consider which of these options have the greater potential impact, under which specific conditions, and in how far they represent realistic policy options.
Notes

Gilles Carbonnier is a professor at the Center on Conflict Development and Peacebuidling (CCDP), Graduate Institute of International and Development Studies, Geneva, Switzerland, and may be reached at gilles.carbonnier@graduateinstitute.ch. The author thanks Jana Krause for research assistance, and Achim Wennmann for comments. A version of this article was presented at the 13th Annual International Conference on Economics and Security, Thessaloniki, 24-26 June 2009, and the author is grateful for the comments of the participants.

1. Demand: Karl (1997); Humphreys (2005); OECD/IEA (2008). "Scramble”: Ghazvinian (2007).

2. Taxes, GDP, ODA: OECD/IEA (2008); World Bank (2007b). Two-thirds: World Bank (2006, p. 77). Breeding ground: Carbonnier (2007). Security threat: Cammack, et al. (2006, pp. ix, 15-16).

3. Perpetuation: Humphreys (2005); LeBillon (2008). Abundance of extractive resources: De Sosa (2002). Policy responses: Carbonnier, Brugger and Krause (forthcoming).

4. Equitable revenue distribution: LeBillon (2008). Key aspect: Wennmann (2007, pp. 87-88).

5. Gas flaring: World Bank (2008). Households: OECD/IEA (2008).

6. End of cold war: Carbonnier (2007). Auty: Auty (1993).

7. Dutch disease: The Economist (1977); Corden and Neary (1982); Ebrahim-Zadeh (2003). Volatility: van der Ploeg and Poelhekke (2008). Institutional dimensions: Shafer (1994); Karl (1997); Ross (1999); Mehlum, et al. (2006); Robinson, et al. (2006); Humphreys, et al. (2007). Political scientists: Beblawi and Luciani (1987); Ross (1999; 2001); Karl (1997); Rosser (2006). Growth and employment: Chabal and Daloz (1999). Rent-seeking behavior: LeBillon (2001; 2008). Not a robust result: Collier and Hoeffler (2004, p. 588); Cramer (2002, pp. 1851-1853).Mono-causal: Ballentine (2003, pp. 259-260). More fundamentally perhaps, moral philosophers raise the question of the ownership of natural resources and the ensuing question of the legitimate right to exploit and sell them (Wenar, 2008). Many national constitutions enshrine the principle that natural resources belong to the state and its citizens. Theoretically thus, no one should be allowed to sell the resources without some sort of permission from the people of a country granting a legitimate right to exploit and market the resources. For practical reasons, the government holds 
custodial rights over the resources. In current practice, it suffices for some governments to maintain coercive control over a territory and its people to be recognized internationally as legally entitled to sell off the country's resources, as exemplified by Equatorial Guinea for instance. In this framework, one may contend that exploiting Equatorial Guinea's oil violates the property rights its people.

8. Opportunity for development: Humphreys, et al. (2007); EITI (2008). Successes: Rosser (2006); Luong and Weinthal (2006, p. 36).

9. Accountability: Beblawi (1987, pp. 49-53, 60-66); Center for the Future State (2005, pp. 4-5). "Rough” companies: Bannon and Collier (2003, pp. 12-15). Private resource ownership: Weinthal and Luong (2006). "Mediated states,” etc.: Menkhaus (2006); Leonard (2008); North, et al. (2007).

\section{Word Bank (2003); Carbonnier (2007).}

11. Questioned: for example, Kolstad and Wiig (2008).

12. Kimberley implementation: Global Witness (2007). Publish what you pay: PWYP/Revenue Watch (2006, p. 8).

13. Second: The Conference Board (2008).

14. Shaxon (2007)

15. Wennmann (2007, p. 84)

16. See “U.S. Energy Security Through Transparency Act (S. 1700).” Available at http://www.govtrack.us/congress/bill.xpd?bill=s111-1700 [accessed 29 July 2010].

17. Export-credit guarantees: Bray (2003, pp. 298-301). Auction system: for example, Luciani (2008).

18. See Eden, Lenway, and Schular (2005).

19. Personal exchanges with members of the Society of Petroleum Engineers (SPE) who want to remain anonymous. The SPE website is http://www.spe.org/index.php.

20. Quote: Humphreys and Sandbu (2007, p. 194). Solutions: Humphreys and Sandbu (2007, pp. 208, 213).

21. Collier, van der Ploeg, Spence, Venables (2009, pp. 34-35).

\section{References}

Auty, R. 1993. Sustaining Development in Mineral Economies: The Resource Curse Thesis. London: Routledge.

Auty, R. 2001. Resource Abundance and Economic Development. Oxford: Oxford University Press.

Ballentine, K. and J. Sherman. 2003. The Political Economy of Armed Conflict: Beyond Greed and Grievance. Boulder: CO: Rienner.

Bannon, I. and P. Collier, eds. 2003. Natural Resources and Violent Conflict: Options and Actions. Washington, D.C.: World Bank.

Barbier, E. 2005. Natural Resources and Economic Development. New York: Cambridge University Press.

Beblawi, H. and G. Luciani. 1987. The Rentier State. London: Croom Helm.

Bray, J. 2003. "Attracting Reputable Companies to Risky Environments: Petroleum and Mining Companies,” in I. Bannon and P. Collier, eds. Natural Resources and Violent Conflict. Washington, D.C.: World Bank.

Cammack, D., et al. 2006. "Donors and the 'Fragile States' Agenda: A Survey of Current Thinking and Practice.” Report submitted to the Japan International Cooperation Agency. London: Overseas Development Group.

Carbonnier, G. 2002. "Corporate Responsibility and Humanitarian Action: What Relations Between the Business and Humanitarian Worlds?” International Review of the Red Cross. No. 844, pp. 947-968.

Carbonnier, G. 2003. "Economie et conflit armé: vers une responsabilité humanitaire de l'entreprise.” Géoéconomie. Vol. 26, pp. 9-36.

Carbonnier, G. 2007. “Comment conjurer la malediction des resources?” Annuaire Suisse de politique de développement. Vol. 26, No. 2, pp. 83-98.

Carbonnier, G. 2008. "Les négociations multi-parties prenantes: l'exemple de l'Initiative de transparence des industries extractives.” Relations internationales. Vol. 136, pp. 101-113.

Carbonnier, G., F. Brugger and J. Krause. (Forthcoming). “Assessing Policy Responses to the Resource Curse: Can Civil Society Live Up to the Expectations?” Global Governance. Vol. 17, No. 2.

Chabal, P. and J.-P. Daloz. 1999. Africa Works. The Political Instrumentalization of Disorder. Oxford and Bloomington, IN: The International African Institute, in association with James Currey.

Coffey International Development Ltd. 2009. "Validation of the Extractive Industries Transparency Initiative (EITI) in The Republic of Azerbaijan.” Reading, Berkshire, UK. Available at: http://www.oilfund.az/pub/uploads/AzerbaijanEITI ValidationFinalReport.pdf.

Collier, P. and A. Hoeffler. 2004. "Greed and Grievance in Civil War.” Oxford Economic Papers. Vol. 56, pp. 563-595. 
Collier, P. 2008. "Global Policies for the Bottom Billion.” London: Progressive Governance. http://www.policy-network.net/publications_list.aspx?Page=4.

Collier, P. 2008. “Implications of Changed International Conditions for EITI.” Oslo: EITI International Secretariat.

Collier, P., F. van der Ploeg, M. Spence, and A. Venables. 2009. "Managing Resource Revenues in Developing Economies.” OxCarre Research Paper 15. Oxford University. http://www.oxcarre.ox.ac.uk/images/stories/papers/ResearchPapers/ oxcarrerp200915.pdf.

Corden, W.M. and J.P. Neary. 1982. "Booming Sector and De-Industrialisation in a Small Open Economy.” The Economic Journal. Vol. 92, No. 368, pp. 825-848.

Cramer, C. 2002.. "Homo Economicus Goes to War: Methodological Individualism, Rational Choice and the Political Economy of War.” World Development. Vol. 30, No. 11, pp. 1845-1864.

De Sosa, I. 2002. "Paradise Is a Bazaar? Greed, Creed, and Governance in Civil War, 1989-99.” Journal of Peace Research. Vol. 39, No. 4, pp. 395-416.

Ebrahim-Zadeh, C. 2003. "Back to Basics: Dutch Disease: Too Much Wealth Managed Unwisely.” Finance and Development. Vol. 40, No. 1. See http://www.imf.org/external/pubs/ft/fandd/2003/03/ebra.htm.

Eden, L., S. Lenway, and D. Schular. 2005. "From the Obsolescing Bargain to the Political Bargaining Model,” pp. 251-273 in R. Grosse, ed. International Business and Government Relations. Cambridge: Cambridge University Press.

Fatal Transaction. 2008. "From Conflict Resources to Sustainable Development." Memorandum by Fatal Transactions tn the European Union on Natural Resource Management in Africa. Amsterdam: http://www.fataltransactions.org/Media/Files/ Dossiers/From-Conflict-Resources-to-Sustainable-Development

Ghazvinian, J. 2007. Untapped: The Scramble for Africa's Oil. New York: Harcourt Books.

Global Witness. 2007. "Loopholes in the Kimberley Process. Illegal Trade Undermines Efforts to Combat Conflict Diamonds.” London: Global Witness.

Humphreys, M. and M.E. Sandbu. 2007. “The Political Economy of Natural Resource Funds,” pp. 194-223 in M. Humphreys, J.D. Sachs, and J.E Stiglitz, eds. Escaping the Resource Curse. New York: Columbia University Press.

Humphreys, M., J.D. Sachs, and J.E. Stiglitz, eds. 2007. Escaping the Resource Curse. New York: Columbia University Press.

Karl, T. The Paradox of Plenty: Oil Booms and Petro-States. Berkeley, CA: The University of California Press.

Kolstad, I. and A. Wiig 2009. "Is Transparency the Key to Reducing Corruption in Resource-Rich Countries?” World Development. Vol. 37, No. 3, pp. 521-532.

Le Billon, P. 2001. "The Political Ecology of War: Natural Resources and Armed Conflicts.” Political Geography. Vol. 20, No. 5, pp. 561-584.

Le Billon, P. 2004. Geopolitics of Resource Wars: Resource Dependency, Governance, and Violence. New York: Taylor \& Francis.
Le Billon, P. 2005. “Fuelling War: Natural Resources and Armed Conflict.” London: Adelphi Paper, No. 373.

Le Billon, P. 2008. "Resources for Peace? Managing Revenues from Extractive Industries in Post-Conflict Environments.” Center on International Cooperation, ed. Political Economy Research Institute.

Lewis, D. 2002. "Civil Society in Non-Western Contexts: Reflections on the 'Usefulness' of a Concept.” Civil Society Working Paper (13).

Luciani, G. 2004. "Oil and Political Economy in the International Relations of the Middle East.” in L. Fawcett, ed. International Relations in the Middle East. Oxford: Oxford University Press.

Luong, P.J. and E. Weinthal. 2006. "Rethinking the Resource Curse: Ownership Structure, Institutional Capacity, and Domestic Constraints.” Annual Review of Political Science. Vol. 9, No. 1, pp. 241-263.

Menkhaus, K. 2007. "Governance without Government in Somalia: Spoilers, State Building, and the Politics of Coping.” International Security. Vol. 31, No. 3, pp. 74-106.

OECD and IEA. 2008. World Energy Outlook 2008 Edition. Vienna: International Energy Agency.

PWYP and Revenue Watch. 2006. "Eye on EITI. Civil Society Perspectives and Recommendations on the Extractive Industries Transparency Initiative.” New York: Revenue Watch Institute.

Robinson, J.A., R. Torvik and T. Verdier. 2006. "Political Foundations of the Resource Curse.” Journal of Development Economics. Vol. 79, No. 2, pp. 447-468.

Ross, M.L. 1999. “The Political Economy of the Resource Curse'.” World Politics. Vol. 51, No. 2, pp. 297-322.

Ross, M.L. 2001. “Does Oil Hinder Democracy.” World Politics. Vol. 53, No. 3, pp. 325-361.

Ross, M.L. 2003. “The Natural Resource Curse: How Wealth can Make you Poor,” in I. Bannon and P. Collier, eds. Natural Resources and Violent Conflict. Washington, D.C.: World Bank.

Ross, M.L. 2004. "What Do We Know about Natural Resources and Civil War?" Journal of Peace Research. Vol. 41, No. 3, pp. 337-356.

Rosser, A. 2006. "The Political Economy of the Resource Curse: A Literature Survey.” Institute of Development Studies at the University of Sussex. Working Paper 268.

Sarraf, M. and M. Jiwanji. 2001. "Beating the Resource Curse: The Case of Botswana.” Departmental Working Paper. Washington, D.C.: World Bank.

Schuhmacher, J.A. 2004. "Introducing Transparency into the Oil Industry. The Quest for EITI." Global Jurist Advances. Vol. 4, No. 3. Article 2. http://www.bepress.com/cgi/viewcontent.cgi?article=1138\&context=gj

Shafer, D.M. 1994. Winners and Losers: How Sectors Shape the Developmental 
Prospects of States. Ithaca, NY: Cornell University Press.

Shaxson, N. 2007. "Oil, Corruption and the Resource Curse.” International Affairs. Vol. 83, No. 6, pp. 1123-1140.

The Economist. 1977. “The Dutch Disease.” London: The Economist.

Van der Ploeg, F. and S. Peolhekke. 2009. "Volatility Harms Growth: New Perspectives on the Natural Resource Curse.” CESifo Working Paper Series, No. 2616.

Wenar, L. 2008. "Property Rights and the Resource Curse.” Philosophy and Public Affairs. Vol. 36, No. 1, pp. 2-32.

Wennmann, A. 2007. “Money Matters: Economic Dimensions of Peace Mediation.” Geneva: Program for Strategic and International Studies. Occasional Paper No. 4.

World Bank. 2008. "World Bank, Partners Aim at Improving Energy Efficiency by Unlocking Value of Wasted Gas.” http://go.worldbank.org/0J1OLOJ880.

World Bank. 2003. "Extractive Industries Review: The World Bank Group and Extractive Industries. The Final Report of the Extractive Industries Review.” Washington, D.C: World Bank. 